\title{
Cunning Passages: Historiography's Ways in and out of the Nuremberg Courtroom
}

\author{
Kim Christian Priemel
}

\begin{abstract}
Starting out from the question of how history and law relate to each other, the article traces the influence of historical interpretations in the making of the Nuremberg Trials, taking these as examples for transitional trials more generally. In trying to explain Germany's apparently aberrant historical evolution, special-path explanations forged by historians gained in prominence after 1933. Several schools of historical thought proved particularly influential, among them the Namierites in Britain, the Andler-Vermeil school of Pangermanism in France, and the so-called Kehrites who emigrated from Germany to the US. These ideas then traveled to Nuremberg where they informed the prosecutors' understanding of German history, leaving a discernible impact on the trials' design and dynamics. In Nuremberg's aftermath, these trial narratives would come to inform influential strands in postwar historiography, with the special path both enjoying popularity and inviting heavy criticism to the present day.
\end{abstract}

\section{Introduction}

$\mathrm{T}$ HE question of just how law and history relate to each other has plagued both disciplines, though historians more than lawyers, for a long time. ${ }^{1}$ Abandoning Hegelian notions of Geschichte als Weltgericht, not a few authors have reflected on the epistemological, methodological, and practical differences between the historian's and the judge's dealings with past events. Notably Marc Bloch, Paul Ricoeur, Reinhart Koselleck, and Carlo Ginzburg have highlighted the common ground in terms of rhetorical tools and forensic instruments without, however, overlooking major differences such as varying concepts of truth (singular v. plural; ultimate v. re/negotiable), analytical proclivities (individual v. structural), or starkly differing consequences (punishment/acquittal v. assessment). ${ }^{2}$ Emphasising the latter rather than the former, critics have discerned a distinct trend in post-1945 jurisprudence to blend judicial and historical investigation and have warned

The present article expands on previous research by the author, using additional sources and widening the chronological scope so as to cover professional historians' debates in the trials' aftermath. I am grateful to various colleagues who commented on earlier drafts at Brussels, Oslo, and Paris, as well as to Central European History's anonymous referees from whose questions and suggestions I have greatly benefited.

${ }^{1}$ Like much of the debate, this article focuses on criminal law rather than the civil and public fields, yet the general points raised would also seem to be pertinent to law's relation with history more broadly.

${ }^{2}$ Marc Bloch, Apologie pour l'histoire ou métier d'historien (Paris: Colin, 1998); Reinhart Koselleck, "Geschichte, Recht und Gerechtigkeit," in Akten des 26. Deutschen Rechtshistorikertages, ed. Dieter Simon (Frankfurt: Campus, 1987), 129-49; Carlo Ginzburg, Il giudice e lo storico. Considerazioni in margine al processo Sofri (Torino: Einaudi, 1991); Paul Ricoeur, La mémoire, l'histoire, l'oubli (Paris: Seuil, 2000). 
against the pitfalls of this convergence. Hannah Arendt's disapproval of the 1961 Eichmann Trial at Jerusalem derived mostly from the (accurate) impression that the prosecution was trying to establish a historical record rather than to mete out punishment, however inadequate, to the man in the glass booth. ${ }^{3}$ More profoundly, Henry Rousso has cautioned that history is not a precise science and should therefore not be mistaken for legally valid expertise in court. Fearing that any testimony invested with the intellectual standing of a well-known academic might run the risk of being accepted in "a synecdochic slippage from what could or might have happened to what actually happened," Rousso famously declined to appear in the Papon trial. ${ }^{4}$

If only it were that simple. Yet "history," as T. S. Eliot once noted, "has many cunning passages," and these passages lead, among others, into and out of the courts of law. The avenues out of the courtroom are fairly well known: trials both assemble and produce what historians consider sources or, as one Nuremberg prosecutor put it, "the raw material of history in wonderful profusion." Judicial proceedings establish chronology and causality, thereby structuring and narrating historical events; and they serve as subjects of historical inquiry in their own right. The narratives that structure judicial proceedings, somewhat misleadingly called the "theory of the trial" by lawyers, ${ }^{6}$ unfold in a dialectic process of indictment, opening statements, briefs, evidence, testimony, closing statements, defendants' final words, and eventually judgment. They provide consistency and coherence to the arguments of the opposed parties but they also bring into the legal arena that which is, strictly speaking, outside the law: broader social context and historical contingency, biographical detail, and situational nuance.

If everyday trials often draw on psychology, criminology, or sociology, historiography underpins "transitional trials," that is, proceedings that take place against the backdrop of regime change or war. Faced with the necessity to draw a firm line between the illegitimate policies of the past and those of the to-be-legitimized present order, history is not only invoked to understand individual crimes but to render comprehensible historical change itself. ${ }^{7}$ Historical narratives lend themselves easily to such uses because of their textuality, which they share with the law along with the methodological common ground both find in exegesis and forensics. As Bruno Latour has observed, "Un bon chercheur comme un bon juriste se reconnaissent à leurs qualités communes d'exégète, à leur unique façon de

\footnotetext{
${ }^{3}$ Hannah Arendt, Eichmann in Jerusalem. A Report on the Banality of Evil (London: Penguin, 2006).

${ }^{4}$ Henry Rousso, "What Court of Judgment for History?", in The Haunting Past: History, Memory, and Justice in Contemporary France (Philadelphia: University of Pennsylvania Press, 2002), 48-83, esp. 59-61. The quote is from Ora Avni, "Foreword to the English-Language Edition," The Haunting Past, vii-xviii, esp. xvii.

${ }^{5}$ An Outline of the Research and Publication Possibilities of the War Crimes Trials, November 1948, Library of Congress (LoC), Charles Fahy Papers, Box 14, Folder Taylor, Telford.

${ }^{6}$ Robert P. Burns, A Theory of the Trial (Princeton: Princeton University Press, 1999).

${ }^{7}$ Ruti Teitel, “Transitional Jurisprudence: The Role of Law in Political Transformation," Yale Law Journal 106 (1997): 2009-80, esp. 2078f. Cf. Nigel Eltringham, “'We Are Not a Truth Commission’: Fragmented Narratives and the Historical Record at the International Criminal Tribunal for Rwanda," Journal of Genocide Research 11 (2009): 55-79; Richard A. Wilson, Writing History in International Criminal Trials (Cambridge: Cambridge University Press, 2011); Marina Aksenova, “The Role of International Criminal Tribunals in Shaping the Historical Accounts of Genocides," in Law and Memory: Towards Legal Governance of History, ed. Uładzislau Belavusau and Aleksandra Gliszczyńska-Grabias (Cambridge: Cambridge University Press, 2017), 48-69.
} 
pondérer des masses de documents hétérogènes en donnant à chacun une valeur de confiance différente." 8

Another of Latour's metaphors, the cheminement (literally the "pathfinding") of legal reasoning, stands at the heart of this article. It explores the means by which history and historiography enter transitional trials and the passages through which they depart again from the legal arena. The key precedents for today's transitional jurisprudence (though not for the much broader field of "transitional justice") were the thirteen trials held at Nuremberg between 1945 and 1949. Here, the self-consciously history-making agenda of the participants would shape the proceedings no less than their understanding of National Socialism, which was, more often than not, informed by the work of amateur and professional historians. Of course, these were not alone in supplying interpretations and narratives to prosecutors, judges, and defense counsel. Other disciplines, including sociology, economics, and anthropology, had their fair share, as did Allied journalists and diplomats whose reports and memoirs of Nazi Germany were widely read, as recent research has shown; however, their tales, too, were essentially historical in nature. ${ }^{9}$ Examples are drawn from American, British, and French historiography. Conspicuously absent is the Soviet case, illustrating the present author's linguistic limitations but also the fact that, apparently, the Soviet team alone among the four Allied delegations at Nuremberg did not include historians in its ranks. ${ }^{10}$

At the heart of historical interpretations then on offer, this article contends, was the diagnosis of deficient modernization. Claiming that Germany had left a common western path and chosen to travel the crooked road toward dictatorship, war, and extermination, the notion of failed modernization favored structural explanations but was often perceived as implying collective responsibility. As such it seemed compatible (and was fatefully equated) with the legal concept of conspiracy that was popular with many prosecutors at Nuremberg. A criminal liability concept, conspiracy tried to cast the net wider by crediting broader strata of German society with guilt for Nazi criminality. In practice, however, the two notions would sit uneasily alongside each other, and the severe criticism directed against real and alleged notions of "collective guilt" would come to harm the general insights historians had meant to offer. The problem, however, did not only lie with the lawyers or the audience in and outside the courtroom. Indeed, the translation of historical concepts into judicially valid categories - or, rather, the failure to appreciate the changes incurred in the process - meant that, once translated, historians would frequently fail to identify in the trial narratives the very interpretations they had coauthored in the first place.

\footnotetext{
${ }^{8}$ Bruno Latour, La fabrique du droit. Une ethnographie du Conseil d'État (Paris: La Découverte, 2004), 22, 236 (quote), 242f. "A good researcher and a good lawyer identify with each other over their shared abilities of exegesis, over their unique way of weighing masses of greatly varying documents while according each a specific value in terms of its trustworthiness" (author's translation).

${ }^{9}$ Ralf Ahrens, "Kartelle und Verschwörungen. Franz Neumanns 'Behemoth' und die Nürnberger Prozesse,” ZeitRäume 4 (2011): 9-17; Alexa Stiller and Kim C. Priemel, eds., Reassessing the Nuremberg Military Tribunals: Transitional Justice, Trial Narratives, and Historiography (New York: Berghahn, 2012); Kim Christian Priemel, The Betrayal: The Nuremberg Trials and German Divergence (Oxford: Oxford University Press, 2016), 36-56. Cf. the Frankfurt School's papers in Raffaele Laudani, ed., Secret Reports on Nazi Germany: The Frankfurt School Contribution to the War Effort (Princeton: Princeton University Press, 2013).

${ }^{10}$ Irina Schulmeister-André, Internationale Strafgerichtsbarkeit unter sowjetischem Einfluss. Der Beitrag der UdSSR zum Nürnberger Hauptkriegsverbrecherprozess (Berlin: Duncker \& Humblot, 2016), 380f.
} 


\section{The Historians' Road to Nuremberg}

For anyone wanting to read up on German history, there was no dearth of material in 1945. A rich literature on what was widely regarded the key power on the European continent had been developing ever since the Franco-German war in 1870-1871 and the establishment of the Reich in its wake. In particular, Prussia's ascendancy to great-power status had been observed with astute interest and growing uneasiness in Europe and abroad. Such concerns had been vindicated by World War I, largely blamed on the Central Powers and accompanied by intense Entente propaganda incriminating - mostly correctly- "Hunnish" atrocities. The Great War had also boosted the market for studies of Germany, with results that varied greatly in character and quality but apparently found an avid readership. William Harbutt Dawson's What Is Wrong with Germany? was merely one of many best-selling books whose title gave away the central message that something was fundamentally wrong with that country, notably its pervasive "spirit of militarism."11 The Weimar Republic's instability in the decade between the Great Inflation and the Great Depression had kept the interest in German political, social, and economic developments alive while Weimar's reputation as the hothouse of cultural modernism had added to the appeal of German studies. $^{12}$

The rise of National Socialism and the creation of the Third Reich continued the riveting story of shifting Teutonic fortunes. When, for the second time in twenty-five years, war broke out in 1939, another massive wave of publications of the understanding-Germany variety flooded the markets. Newspapers and magazines ran cover stories and long reports of life in "Hitler's Germany" while sixpenny pamphlets summarized the German national character's peculiarities for popular consumption. Academic journals and policy newsletters debated Nazi strategy and tactics while book-length studies inquired into the profounder causes for renewed catastrophe. Much of the writing during the war years never made its way to the printing press: government agencies, international organizations, and think tanks engaged, in varying degrees, in enemy studies, drafting papers and reports that circulated within the ever-expanding apparatus of wartime administration and in particular in those branches that were charged with postwar planning. Significantly, however, there was a great degree of permeability between the different spheres and genres: classified documents drew on published works while research conducted in official function fed into publications; academics from all disciplines were recruited by wartime agencies, and politicians and professors exploited their pamphleteering talents; first-hand experience and detached analysis were frequently indistinguishable. ${ }^{13}$ Most of all, however, virtually all studies of Nazism agreed on one salient fact: that a distinct historical trajectory had led Germans astray from a standard western path of modernity with its institutional hallmarks such as democracy and pluralism, the rule of law and private-property-based capitalism. ${ }^{14}$

\footnotetext{
${ }^{11}$ William Harbutt Dawson, What Is Wrong with Germany? (London: Longmans, 1915), ix.

${ }^{12}$ See, for example, Richard Scully, British Images of Germany: Admiration, Antagonism \& Ambivalence, 1860-1914 (London: Palgrave Macmillan, 2012), and Katja Marmetschke, Feindbeobachtung und Verständigung. Der Germanist Edmond Vermeil (1878-1964) in den deutsch-französischen Beziehungen (Cologne: Böhlau, 2008).

${ }^{13}$ See Michaela Hönicke Moore, Know Your Enemy: The American Debate on Nazism, 1933-1945 (Cambridge: Cambridge University Press, 2010).

${ }^{14}$ Cf. Kim Christian Priemel, “A Story of Betrayal': Conceptualizing Variants of Capitalism in the Nuremberg Trials," Journal of Modern History 85 (2013): 69-108.
} 
In short, various epistemic communities-usually separated by different disciplinary backgrounds no less than by varying, often strongly opposed political creeds-converged on historical interpretations at the center of which stood the idea of a Sonderweg, a special path, which set Germany apart from its western neighbors (though not necessarily from those to the east, especially not the Soviet Union). Allied intellectuals and émigré scholars, bureaucrats and foreign-policy pundits, pacifists and military men found that, whatever their differences in detail or in the conclusions they drew, there was a near-universal consensus on German aberration. As if in a lens these interpretations of how Germany had forsaken the standards and ethics of western civilization - a construct that itself was hardly ever questioned $^{15}$ - and had committed crimes on an unprecedented scale converged at Nuremberg. There, international law, whose operational logic was the very belief in (western) civilization as a community of shared values, ${ }^{16}$ provided the framework in which the story of divergence would be told.

Thanks to exile and emigration, the debate on German divergence transcended the predominantly national patterns of historiography: French scholars found themselves lecturing in London and New York to audiences made up of nationals of various occupied countries and, of course, to their British and American peers; German exiles-socialists, liberals, or conservatives of varying hues - enlisted with US wartime organizations where they joined hands with their colleagues from American universities. This amalgamation was particularly notable in the United States where government recruitment of "enemy aliens" was more inclusive than in Britain and pragmatism reigned supreme. The head of the newly established intelligence agency Office of Strategic Services (OSS), William Donovan, had no reservations about hiring known socialists so long as these offered talents that would help win the war. Indeed, various government bodies such as the US Army, the Board of Economic Warfare, or the Office of War Information recruited a broad spectrum of refugees that ran the gamut from liberal Austrian economists to unorthodox Marxists.

Notably, OSS became a vibrant hub of émigré scholars who brought their intimate knowledge of Germany along with their investigative and analytic skills. Among them were several young historians such as Felix Gilbert and Hajo Holborn, who had fled from the Reich and were now teaching at universities and colleges, mostly on the East Coast. In the offices of OSS, in particular those of its brains and archives, the Research \& Analysis branch (R\&A), they met their peers, junior historians from those same institutions, such as Carl Schorske, Eugene Anderson, Gordon Craig, Walter Dorn, or Leonard Krieger. The density of scholars of modern European history was no accident. R\&A's head, William L. Langer, himself hailed from Harvard and was a prominent name in diplomatic history. His younger colleagues shared his research interests in European imperialism on which he had written extensively, with his magisterial The Diplomacy of Imperialism as the leading American publication in the field. ${ }^{17}$

\footnotetext{
${ }^{15}$ See the excellent volume by Riccardo Bavaj and Martina Steber, eds., Germany and "the West": The History of a Modern Concept (New York: Berghahn, 2015).

${ }^{16}$ See Gerrit W. Gong, The Standard of "Civilization" in International Society (Oxford: Clarendon Press, 1984), and the contributions to Anne Orford, ed., International Law and Its Others (Cambridge: Cambridge University Press, 2006).

${ }^{17}$ William L. Langer, The Diplomacy of Imperialism 1980-1902, 2 vols. (New York: Knopf, 1935); cf. Carl Schorske, "Introduction," in William L. Langer, Explorations in Crisis: Papers on International History, ed. Carl E. Schorske and Elizabeth Schorske (Cambridge, MA: Belknap, 1969), ix-xliv.
} 
Moreover, Langer's historians shared his appreciation of a crucial turn that had lately occurred in the literature on imperialism: the second edition of his Diplomacy was supplemented by a range of references to the late Eckart Kehr, the enfant terrible of German interwar historiography. His analysis of naval armament policy in the Wilhelmine empire had turned conventional wisdom on its head: German imperialist expansion had not been determined by foreign-policy considerations but by the "primacy of domestic politics" that had been dominated by the fateful coalition of large-scale agrarian producers-the notorious Junkers-and industrial pressure groups, notably those of Westphalian heavy industry. In Kehr's analysis this alliance of bourgeois capital with the reactionary Prussian landed gentry had compromised any socially and politically modernizing effects of the emerging high-capitalist economy while at the same time channeling popular energies through nationalist conduits. ${ }^{18}$

Despite his own more traditional stance, Langer appreciated the heuristic potential of adding a socioeconomic perspective to the study of imperialism, and he also took note of Kehr's followers and friends, including George Hallgarten and Alfred Vagts (who helped promoting Kehr's work in the United States in the early 1930s). ${ }^{19}$ Although Hallgarten and Vagts signed up with the US Army and the Board of Economic Warfare (BEW), respectively, Langer's own staff included several admirers of Kehr's work. Gilbert and Holborn had recognized Kehr as the intellectual ringleader of their generation and found that their American peers were highly interested in his work. Three decades later Eugene Anderson and his wife, Pauline, would still think it worthwhile jointly editing Kehr's principal writings. ${ }^{20}$

The broader appeal of this historical paradigm shift beyond the confines of historiography owed much to its theoretical underpinnings, drawing mostly on Max Weber but also on Karl Marx and Thorstein Veblen, which made it compatible with the works of a number of sociologists and lawyers who stood squarely in the same tradition. It was no accident that members of the exiled Frankfurt School helped distribute Hallgarten's unpublished manuscript on German imperialism in the United States. ${ }^{21}$ Namely lawyer-cum-sociologist Franz L. Neumann drew strongly on Kehrite historiography. His famous Behemoth (1942) depicted Nazi Germany as an institutionalized compromise of party, military, civil service, and big business, duly referencing Kehr, Vagts, and Langer. The latter, by then, was

\footnotetext{
${ }^{18}$ Eckart Kehr, Schlachtflottenbau und Parteipolitik 1894-1901. Versuch eines Querschnitts durch die innenpolitischen, sozialen und ideologischen Voraussetzungen des deutschen Imperialismus (Berlin: Ebering, 1930); Eckart Kehr, Der Primat der Innenpolitik. Gesammelte Aufsätze zur preußisch-deutschen Sozialgeschichte im 19. und 20. Jahrhundert, 2nd ed. (Berlin: DeGruyter, 1970).

${ }^{19}$ Arthur Lloyd Skop, "The Primacy of Domestic Politics: Eckart Kehr and the Intellectual Development of Charles A. Beard," History and Theory 13 (1974): 119-31; William Langer, "Review of: Vorkriegsimperialismus by Wolfgang Hallgarten," American Historical Review 46 (1940): 142-43.

${ }^{20}$ Felix Gilbert, A European Past. Memoirs 1905-1945 (New York: Norton, 1988), 71; Eckart Kehr, Battleship Building and Party Politics in Germany, 1894-1901: A Cross-section of the Political, Social and Ideological Preconditions of German Imperialism, ed. and trans. Pauline $\mathrm{R}$. Anderson and Eugene N. Anderson (Chicago: University of Chicago Press, 1973). Anderson had known Kehr as well as Hans Rosenberg, another German émigré scholar, since 1931: Gerhard A. Ritter, "Introduction," in German Refugee Historians and Friedrich Meinecke: Letters and Documents, 1910-1977 (Leiden: Brill, 2010), 1-114, esp. 94.

${ }^{21}$ See the preface to George W. F. Hallgarten, Imperialismus vor 1914. Die soziologischen Grundlagen der Außenpolitik europäischer Großmächte vor dem Ersten Weltkrieg, 2nd ed. (Munich: Beck, 1963); Holborn to Vagts, October 4, 1939, Bundesarchiv (BA), N 1269/2.
} 
Neumann's boss, as the émigré scholar had also joined R\&A's Central Europe section, where he quickly assumed the intellectual leadership. Neumann as well as Otto Kirchheimer, Herbert Marcuse, and John Herz employed the concepts provided by their historian colleagues at OSS and would feed these into the dossiers they prepared for the Nuremberg prosecution in $1945 .^{22}$

Not wholly surprisingly given their own background, these scholars did not argue along ethnic lines and rejected any notion of Germans showing a natural propensity for authoritarianism, nationalism, and aggression. Nor did they consider Germans wholly unfit for liberal democracy, as not a few contemporaries understood the diatribes of Lord Vansittart but also Henry Morgenthau's tract Germany Is Our Problem, despite its rather different angle. ${ }^{23}$ Instead they proposed a stringent historical reading in which authoritarian forces had captured German politics in the nineteenth century, following the defeat of the 1848-1849 revolution and the subsequent defection of the liberal-bourgeois forces to the conservative-reactionary camp. Although the philosophical currents of Historicism and Romanticism had prepared the intellectual ground for nationalism and its peculiar emphasis on the Volk, Prussian ascendancy among the German states had added militarism to the brew. Finally, the agrarian-industrial coalition, prepared in Bismarck's time, had been a key player in radicalizing the imperialist swing of the Wilhelmine age. Pan-Germanism was a prominent figure in these accounts, joining together radical nationalism, violent antisemitism, and aggressive expansionism (especially eastward), as well as linking pre-1914 foreign policy to that of the 1930s, as Langer noted in a sorrowful essay against the backdrop of failed appeasement: "At bottom, there is very little originality in any of the teachings of National Socialism. They are really little more than a projection and adaptation of the ideas of German nationalism and Pan-Germanism as they have been advanced for a hundred years." 24

The concept of Pan-Germanism was also familiar to the discipline of Germanistique in France, which had rapidly grown since 1871 and, again, during World War I. In his 1915 study, Charles Andler had accounted for aggressive Pan-Germanism-in contrast to his colleague Henri Lichtenberger, who understood German politics as integral to European imperial rivalry-by finding an essential difference between French and West European culture, steeped in the Greco-Roman tradition, on the one hand, and its German antagonist, veering to the east, on the other. ${ }^{25}$ Andler's foremost disciple was Edmond Vermeil, whose "science de l'Allemagne" would provide two generations of French with an image of Germany. ${ }^{26}$ Vermeil's Les doctrinaires de la révolution allemande (1938) and L'Allemagne: Essai d'explication (1940) placed Pan-Germanism center stage in the analysis of National Socialism. Reaching as far back as the Carolingian age, Vermeil distinguished between the occidental heritage of Germany's western, Rhenish parts, and the Germano-Slavonic

\footnotetext{
${ }^{22}$ A number of these papers have been published in Laudani, Secret Reports on Nazi Germany.

${ }^{23}$ Cf. Jörg Später, Vansittart. Britische Debatten über Deutsche und Nazis 1902-1945 (Göttingen: Wallstein, 2003).

${ }^{24}$ William L. Langer, "When German Dreams Come True," in Explorations in Crisis, 227-43, esp. 228. Cf. Franz Neumann, Behemoth: The Structure and Practice of National Socialism, 1933-1944, 2nd ed. (Oxford: Oxford University Press, 1944 [Reprint Chicago: Ivan R. Dee, 2009]), 109-11, 204-07.

${ }^{25}$ Charles Andler, Le Pangermanisme. Ses plans d'expansion allemande dans le monde (Paris: Colin, 1915). Cf. Marmetschke, Feindbeobachtung und Verständigung, 142-45.

${ }^{26}$ According to Pierre Ayçoberry, La question nazie. Les interprétations du national-socialisme (1922-1975) (Paris: Seuil, 1979), 73.
} 
traditions of the East, notably in Prussia. Although pointing to distant processes such as German regional dualism or the Reformation with its Lutheran creed of authoritarian subservience to the state, Vermeil, too, considered the nineteenth century the decisive period in German history. Having missed the once-in-a-nation's-lifetime chance of cosmopolitan conversion in the classicist age, Germany had been thoroughly Prussianized, with the remnants of its western legacy purged, and harnessed to the principles of Pan-Germanism, which were "antisémite, antiromain, délibérément hostile au christianisme œcuménique ..., au libéralisme démocratique et à toutes les Internationales socialistes." In a bleak conclusion, the Sorbonne professor stipulated that "L'antithése entre Est et Ouest est encore plus riche de sens. Elle correspond à la formation historique de la population allemande." 27

A German studies scholar rather than a trained historian, Vermeil earned scathing criticism from the profession. In particular, the early Annales School, with its distaste for the history of events and its call for rigorous methodology had little use for what Lucien Febvre and Marc Bloch considered "[une] purée metaphysico-catholico-luthérienne." 28 But such academic snubs aside, Vermeil's writings were a manifest success. His Essai was reprinted repeatedly, and the revised 1945 edition would manage a staggering eight editions in just one year as well as inspire similar syntheses, including Jacques Droz's contribution to the popular Que sais-je? paperback series. ${ }^{29}$

Vermeil's Essai also appeared in an English translation, and it may have been either this or the original French version that found its way to the desk of A. J. P. Taylor when he was working on his notorious The Course of German History during the latter phase of the war. Taylor, then in his late thirties (and, like Langer, one of those Anglo-American students who had been tutored by Alfred Prribram in interwar Vienna), had emerged as a leading historian of modern Europe, notably with monographs on The Italian Problem in European Diplomacy (1934), Germany's Bid for Colonies (1938), and his weighty account of The Habsburg Monarchy (1941). Much of his work was deeply concerned with what he considered the heart of Europe's troubles - the struggle for mastery in Europe (as he would sum it up in a 1954 book title) between the great powers, which, for all practical concerns, he considered more or less identical with Germany's struggle for mastery over Europe in the past hundred years. ${ }^{30}$ The two German states-Austria and the Prussian-dominated Reich-occupied Taylor's historiographical work but also his output as a public intellectual. Taylor responded

\footnotetext{
${ }^{27}$ [The principles of Pan-Germanism are] "antisemitic, anti-Romanic, deliberately hostile to ecumenical Christianity [as well as] to democratic liberalism and to all socialist Internationals.... The contrast between East and West is even more thought-provoking. It corresponds to the historical formation of the German people," Vermeil, L'Allemagne, 197, 307. Cf. Ayçoberry, La question nazie, 70f., and Marmetschke, Feindbeobachtung und Verständigung, 413-30.

${ }^{28}$ A "metaphysical Catholic-Lutheran mash"; quoted from Marmetschke, Feindbeobachtung und Verständigung, 346. However, Bernhard Escherich, Herausforderung Deutschland. Zum Deutschlandbild französischer Historiker 1945-1989 (Hamburg: Kovac, 2003), 68, notes that Febvre, too, distinguished between a Roman-European history of Rhenish Germany and the culturally eastern and aggressively militarist Prussian territories.

${ }^{29}$ Marmetschke, Feindbeobachtung und Verständigung, 452f.; Escherich, Herausforderung Deutschland, 112-17, 140-45, 313f.

${ }^{30}$ For a succinct discussion of Taylor's writings see Robert Cole, A.J. P. Taylor: The Traitor within the Gates (Basingstoke: Macmillan, 1993); on his biography see Adam Sisman, A. J. P. Taylor: A Biography (London: Sinclair-Stevenson, 1994), Chris J. Wrigley, A. J. P. Taylor: Radical Historian of Europe (London: Tauris, 2006), and Kathleen Burk, Troublemaker: The Life and History of A. J. P. Taylor (New Haven: Yale University Press, 2000).
} 
keenly when His Majesty's Government's political warfare executive approached him with an eye to writing first a handbook on Hungary for the British troops (but rejected the draft Taylor presented), then a paper on Weimar Germany. That, again, was not accepted for publication, apparently on account of its pessimistic evaluation of Nazism as the historically consequent result of Germany's failed political evolution. Undeterred, Taylor expanded the manuscript into a full-blown monograph, which he published with Hamish Hamilton in 1945 - and which, thanks to its topical character as much as to Taylor's spirited, witty, and more often than not polemical prose, became an instant success in the United Kingdom. ${ }^{31}$

Building on Vermeil as well as on Kehr, as Taylor later acknowledged, ${ }^{32}$ well-known tropes characterized The Course of German History: German dualism, Lutheran antiwesternism, the lingering feudalism sustained by the Prussian Junkers' preeminence, and the general backwardness of an insufficiently modernized German society. In one of the many quotable passages of his tome, Taylor described Prussian Junkers as "politically in the Stone Age; economically and administratively they looked forward to the age of steel and electricity. They were barbarians who had learnt to handle a rifle and, still more, bookkeeping by double entry. Ruthless exploiters of conquered land, they were untouched by European civilization and yet could master every technical improvement which Europe produced." 33 The poverty of Historicism (to borrow the title of Karl Popper's contemporary work) figured as prominently as the failure of 1848's liberal revolutionaries. German capitalists appeared on Taylor's stage as "dependants of Prussian militarism and advocates of arbitrary power" as opposed to their British and American counterparts who had "as naturally and as inevitably ... become liberals and advocates of constitutional authority. ${ }^{34}$ Pan-Germanism, too, was referenced as the ideological glue binding together the not entirely reconcilable interests of Germany's elites - "the generals, the judges, the civil servants, the professional classes." Taylor argued that "demagogic Pan-Germanism could not succeed without the backing of the Junkers and the great industrialists; the Junkers and great industrialists could not maintain themselves without the backing of demagogic Pan-Germanism." Reminiscent of Neumann's four pillars of the Nazi state, this view would come to inform the Nuremberg trials' design and its choice of defendants. ${ }^{35}$

The Course of German History was neither the first nor the most vociferous of its brand on the British print market. But it combined easy accessibility and great entertainment with the reputation of its author. By comparison, the inquiry that Rohan D'Olier Butler-an All Souls fellow who joined the wartime Ministry of Information before transferring to the Foreign Office in 1944-undertook into the spiritual and intellectual origins of National Socialism were far more sober and more academic in style; where Taylor preferred the gibe over nuance, Butler paid homage to the footnote. In their identification of the roots of the German problem, however, there was not much difference. Naming Vermeil's Doctrinaires as one of the key works that had inspired his own study, Butler discussed Romanticism and Historicism at length, censured Hegelianism as "a sombre doctrine of

${ }^{31}$ Burk, Troublemaker, 245-54; Sisman, A. J. P. Taylor, 146-55.

${ }^{32}$ A. J. P. Taylor, A Personal History (London: Hamish Hamilton, 1983), 172.

${ }^{33}$ A. J. P. Taylor, The Course of German History. A Survey of the Development of German History since 1815, with a new introduction by Chris Wrigley (London: Routledge, 2001 [1st ed. 1945]), 21f.

${ }^{34}$ Taylor, The Course of German History, 61, 71, esp. 95f.

${ }^{35}$ Taylor, The Course of German History, 252, 259. 
strife," linked all with Prussianism, and inevitably came across Pan-Germanism, too. ${ }^{36}$ Yet the key point Butler made was what he considered German anti-individualism, the primacy accorded to the Volk by Romantic philosophy: "Here at once we come upon the fundamental cleavage between Germany and the west. A cardinal tenet of all western thought is the sanctity of the individual.... But the German spirit tends to view the individual otherwise, according to him no sanctity as such, dwelling upon his imperfections, and judging him insufficient. Hence the German addiction to drill, rank and organization, to the superpersonal hierarchies and formations which alone can bestow upon such an individual that poise and significance which he is incapable of deriving from, or ascribing to, himself...."37

Rather more pointed was the comment of Butler's colleague, fellow Oxford historian A. L. Rowse: "The simple German soul! On a par with the sausages, the wuerstchen.... Bloody idiots," his diary read on April 6, 1936, after witnessing popular enthusiasm over the remilitarization of the Rhineland. Rowse elaborated the theme in a Political Quarterly article four years later. In an unacknowledged paraphrase of Dawson's 1915 book, he asked "What is wrong with the Germans?" and offered a damning answer just a few lines below: "the nature of the German mind, or at any rate the dominant German mind, for the last hundred years, its essential difference from the mind of civilised Europe, north, west and south." Conspicuously absent from Rowse's directions was the east, indicating that this was where German mentality was at home. ${ }^{38}$

\section{Historiography at Work}

Only a few of the historians and their fellow academics would actually travel to Nuremberg, but their books and articles, their memoranda and reports did. The R\&A scholars spent much of summer 1945 composing long dossiers for the uses of the Nuremberg prosecution. These did not only shed light on the intricate institutional network of the Third Reich but provided overarching interpretations of Nazi rule, its origins, dynamics, and criminal results. Although a master narrative- which was tailored to the needs of the American prosecution's tactics of charging a comprehensive design to commit a vast array of crimes, thus tying up all particulars in one, broad story-was provided under Marcuse's supervision in "Nazi Plans for Dominating Germany and Europe," 39 several substudies spelled out specific subjects: (a) domestic crimes and those committed in various occupied territories; (b) the structure and internal workings of various state and party organizations; (c) particular types of crimes such as the "euthanasia" murders; and (d) structural analyses of themes such as the adaption of Germany's cartelized economy to the needs of rearmament and war production or the changes in the Reich's criminal law system. ${ }^{40}$ More such memoranda were sent to

\footnotetext{
${ }^{36}$ Rohan D'O. Butler, The Roots of National Socialism 1783-1933 (New York: Fertig, 1968 [1942]), 76f. Cf. similar reflections by literary scholar S. D. Stirk, The Prussian Spirit: A Survey of German Literature and Politics 1914-1940 (London: Faber \& Faber, 1941).

${ }^{37}$ Butler, The Roots of National Socialism 1783-1933, 193-95, 288. For the religious undertones in analyses of German or Prussian culture, see Stirk, The Prussian Spirit, 218-23.

${ }^{38}$ A. L. Rowse, "What Is Wrong with the Germans?," Political Quarterly 11 (1940): 16-29; A. L. Rowse, The Diaries of A. L. Rowse, ed. Richard Ollard (London: Penguin, 2004), 89.

${ }^{39}$ Nazi Plans for Dominating Germany and Europe. Draft for the War Crimes Staff, August 7, 1945, National Archives and Record Administration (NARA), RG 238, Entry 45, Box 2, Folder R\&A No. 3114.

${ }^{40}$ Principal Nazi Organizations Involved in the Commission of War Crimes. Nazi Racial and Health Policy. Draft for the Use of War Crimes Staff, August 15, 1945, NARA, RG 238, Entry 45, Box 2,
} 
Nuremberg from the BEW (now renamed Foreign Economic Administration) and the US Department of Justice as well as from the British Foreign Office. So were a great number of monographs and journals that provided background information, including instant classics such as Neumann's Behemoth, as well as specialized works such as Bernhard Menne's muckraking history of Krupp (Blood and Iron), which was strongly indebted-as both interpretation and bibliography showed-to the writings of Kehr and Hallgarten. ${ }^{41}$

The OSS intellectuals' contribution did not stop at providing background reading, though. In the early days of trial preparation, the US chief of counsel, former Attorney General and now Supreme Court Justice Robert H. Jackson, relied heavily on the expertise assembled by R\&A, and his team consulted with the researchers on a regular basis. ${ }^{42}$ Donovan himself was appointed to a short-lived deputyship of Jackson's while R\&A members Neumann and Herz were delegated to Nuremberg. ${ }^{43}$ Thus, an early list of possible defendants for the forthcoming International Military Tribunal (IMT) accorded responsibility not only to the notorious survivors of Hitler's inner circle but also to representatives from various powerful groups. Jointly assembled by Langer, Neumann, and Schorske, the roster of thirty defendants included businessmen such as Alfred Krupp and Hermann Röchling, second-tier ministerial officials such as Wilhelm Stuckart and Paul Körner, and Volksgerichtshof vice president Wilhelm Crohne. ${ }^{44}$

But not all was milk and honey between the courtroom lawyers and the academics on Jackson's staff. Herz and Neumann, though trained jurists, were disappointed by the intellectual standards of their lawyering colleagues and by how little these cared for sociological complexity and interpretative nuance. The degree to which their explanations were reduced to the simplest of narratives frustrated a political scientist such as Neumann, who felt that the R\&A memoranda appeared insufficiently read or understood by Jackson' attorneys. ${ }^{45}$ The chief of counsel, meanwhile, did not think this much of a loss. Two months into the trial preparation, the Justice found his historical background sufficiently updated and let it be known that henceforward the trial would be "a lawyer's job." 46 Neumann was the not the only scholar to despair of (American) attorneys. His counterpart in the British delegation, Sidney Sussex fellow and Foreign Office librarian Ernest James Passant, also found that much of what he had to offer tended to fall on deaf ears. On his own team, the British

Folder R\&A No. 3114.7; Nazi Changes in Criminal Procedure, July 10, 1945, NARA, RG 153, Entry 135 , Box 13, L-216; Nazi Plans for Dominating Germany and Europe. Domestic Crimes. Draft for the War Crimes Staff, August 13, 1945, Cornell Law Library, DNTC, vol. III, 7.25; Principal Nazi Organizations Involved in the Commission of War Crimes. Nazi Spoliation of Property in Occupied Europe. Draft for the War Crimes Staff, July 24, 1945, NARA, RG 238 Entry 45, Box 1, Folder R\&A No. 3113.6.

${ }^{41}$ See Priemel, The Betrayal, 97f., 173-75.

${ }^{42}$ See, for example, notes on conference, June 25, 1945, on NSDAP, SS, SD, Gestapo, and Police as criminal organizations, NARA, RG 238, Entry 52E, Box 3, Folder 60.

${ }^{43}$ Preparation of International War Crimes Prosecution, June 16, 1945, NARA, RG 226, Entry 146, A-1, Box 37, Folder Charts.

${ }^{44}$ Memorandum to All Members of the Staff, June 26, 1945, NARA, RG 238, Entry 52E, Box 10, Folder 312.2 .

${ }^{45}$ Neumann to Kent, Schorske, Burckhardt, August 3, 1945, NARA, RG 226, Entry 1, Box 2, Folder WCP45; John H. Herz, Vom Überleben. Wie ein Weltbild entstand. Autobiographie (Düsseldorf: Droste, 1984), 140-42.

${ }^{46}$ Saturday Morning Meeting, August 11, 1946, LoC, Robert H. Jackson Papers, Box 107, Folder PreTrial Planning. 
War Crimes Executive (BWCE), chief prosecutor Hartley Shawcross would eventually make very little use of the historical material Passant had provided for the British opening statement, instead relying largely on the strictly jurisprudential arguments that Britain's leading international law scholar, Hersch Lauterpacht, had drafted. ${ }^{47}$

Passant's position is particularly interesting: influenced by Weber's work, he had penned a short modern history of Germany during the war that read like sanitized A. J. P. Taylor. Indeed, Passant had taken Taylor's place in the political warfare executive's book project and, when published much later, he meticulously referenced The Course of German History. Clearly, Passant was not adverse to historical conceptualizations in the judicial framework, but he also had a clear sense of how far these would go. More than once he counseled against American enthusiasm for indicting Gustav Krupp, Hjalmar Schacht, Karl Doenitz, or Karl Haushofer, reminding his colleagues that any such effort would be wide open to accusations of hypocrisy given the Allies' own record in armaments production, public finance, naval warfare, or the theory of geopolitics. However, only Haushofer escaped indictment (and Krupp the trial because of his poor health), whereas the Schacht acquittal and Doenitz's lenient sentence would vindicate Passant's misgivings. ${ }^{48}$

Jackson's own version of modern German history, offered with considerable rhetorical flourish in his opening statement in November 1945, justified some of the academics' concerns. The speech repeatedly referenced the special path paradigm while Jackson's invocation of a terrible triumvirate made up by "the Nazi revolutionists, the most unrestrained of the German reactionaries, and the most aggressive of the German militarists" suggested that the papers supplied by Neumann had not completely gone to waste. Dominant, however, was the notion of a criminal conspiracy, which, starting as a mode of liability in order to assign guilt to those perpetrators remote from the crime scenes, had become the US prosecution's main narrative, chiming in with widespread tropes of Nazi "gangsters," "thugs," and a criminal "clique." Such metaphors and analogies, French prosecutor Edgar Faure astutely realized, offered great exculpatory potential- "Leur condemnation, c'est ton acquittement"- to the vast majority of Germans. ${ }^{49}$ And it was precisely for this reason that they proved so popular in Germany where allegations of collective guilt were preemptively refuted even before Jackson assured the audience that "we have no purpose to incriminate the whole German people." Ironically, the conspiracy concept-whose legal adequacy was doubted by not a few jurists and which would fare rather badly in the eventual judgment-therefore had its greatest effect as a tool to repudiate collective responsibility and undermine the failed-modernization theory it originally built on. ${ }^{50}$

\footnotetext{
${ }^{47}$ Cable \#31414 from London dated June 1, 1945, for Mr. Justice Jackson, June 8, 1945, NARA, RG 226, A-1, Entry 146, Box 37, Folder 500; David Maxwell-Fyfe to Sylvia Maxwell-Fyfe, November 10, 1945, Churchill College Archives, KLMR/Acc. 1485, Box 1.

${ }^{48}$ Memorandum. Keitel, Doenitz, Schacht and Krupp as War Criminals, August 15, 1945, CLS, TTP-201-2-17a; Minutes of Meeting of Committee Four, September 10, 1945, HSTL, Katherine Fite Papers, Box 2, Folder Evidence/MWC 3. Wrigley, A.J. P. Taylor, 154; Duncan Kelly, "Reconfiguring Reason of State in Response to Political Crisis," in Law, Liberty and State. Oakeshott, Hayek and Schmitt on the Rule of Law, ed. David Dyzenhaus and Thomas Poole (Cambridge: Cambridge University Press, 2015), 185-213, esp. 202-03.

${ }^{49}$ Edgar Faure, Mémoires II. "Si tel doit être mon destin ce soir..." (Paris: Plon, 1984), 62-64.

${ }^{50}$ Quotes: Trial of the Major War Criminals Before the International Military Tribunal, Nuremberg 14 November 1945-1 October 1946, 42 vols. (Nuremberg: no publ., 1947-1949) [henceforth IMT], II, 120f. For a critical
} 
Yet it is a metonymic mistake to hold Jackson's opening and closing speech as characteristic of the Nuremberg prosecution in general. In fact, the Justice's interpretation, although shared by many members of his staff as well as those of other teams, did not represent the mainstream of arguments made at Nuremberg. Various qualifications are necessary: the distinction between the four-power IMT and the fourteen subsequent cases run independently (but interrelatedly) by American, French, and British forces; discrepancies between the different delegations at the IMT; and indeed the coexistence of varying interpretations within Jackson's own team. This showed clearly in the prosecution of the Wehrmacht high command and the general staff, two of the indicted organizations before the IMT. The case, jointly prepared by British lawyer Peter Calvocoressi and his American peer Telford Taylor, soon to become Jackson's successor as chief of counsel in the subsequent proceedings, set out to do what Holborn had demanded back at the outset of the war. If anything good was ever to come out of Germany again, the historian had told his colleague Vagts, "It is not only the Nazis who must go but also the political generals." ${ }^{1} 1$ This was very much Taylor's stand, who considered his portion of the trial part and parcel of the Allied objective "to do everything possible to root out the German military tradition and stamp out the German General Staff and Staff Corps tradition." 52 Accordingly, the organization case prepared under the direction of Calvocoressi and Taylor bore the imprint of historical readings resembling those of Langer, Vermeil, and A. J. P. Taylor, while directly quoting from the memoirs of Sumner Welles, FDR's undersecretary of state, in which the German general staff appeared very prominently as a malign force of pan-German aggression. ${ }^{53}$

Telford Taylor's own rhetoric was hardly less poignant. In court, he identified militarism as the common ground of Nazi Party and Wehrmacht: "Militarism is not the profession of arms. Militarism is embodied in the 'military-minded nation' whose leaders preach and practice conquest by force of arms, and relish war as something desirable in itself. Militarism inevitably leads to cynical and wicked disregard of the rights of others and of the very elements of civilization. Militarism destroys the moral character of the nation that practises it and, because it can be overthrown only by its own weapons, undermines the character of nations that are forced to combat it. The wellspring of German militarism through the years had been the group of professional military leaders who have become known to the world as the "German General Staff."' And although not exclusive to Germans, militarism had historically "flourished far more widely and obstinately in Germany than elsewhere." 54

Taylor's formula that militarism was "something big and evil and durable; something that was not born in 1933, or even 1921; something much older than anyone here; something far more important than any individual in the dock" would later reappear in the Krupp and high command cases of the subsequent proceedings. There, the alleged alliance between the Junker elites and their military branch, the Prussian army, with heavy industry supplied a

\footnotetext{
reading see Donald Bloxham, Genocide on Trial. War Criminals and the Formation of Holocaust History and Memory (Oxford: Oxford University Press, 2001).

${ }^{51}$ Holborn to Vagts, 4.10.1939, BA, N 1269/2 [my translation].

${ }^{52}$ Memorandum for Mr. Justice Jackson, 30.8.1945, HLL, Leonard Wheeler Papers, Box 3, Folder 3-6.

${ }^{53}$ IMT, IV, 496; IMT, XXII, 271-97; cf. Sumner Welles, The Time for Decision (New York: Harper, 1944), $337-39,342,356-58$.

${ }^{54}$ IMT, XXII, 295-97.
} 
cornerstone to the prosecution narrative. ${ }^{55}$ Compelling as it must have sounded to many contemporaries, however, the argument met with mixed results on the bench. Whereas the IMT judges accepted the prosecution's notion of a specific, perilous German militarism, ${ }^{56}$ their successors in the American-run Nuernberg Military Tribunals (NMT) skirted the historical debate wherever possible. Professionally more conservative minded and reticent to both innovating international criminal law and dabbling in the writing of history, they preferred plainly criminal facts such as atrocity and murder charges. In the judgments of the socalled Hostage and High Command cases at Nuremberg, but also in that of the British sibling trial of Field Marshall von Manstein at Hamburg, history was largely relegated to the sidelines. ${ }^{57}$

Taylor and Calvocoressi made for an interesting team. Both young and widely considered rising stars, the pair displayed a discernible penchant for history, which they had studied before taking up law and to which they would return in their respective postwar careers. ${ }^{58}$ Oxford trained, Calvocoressi had been tutored by Lewis B. Namier, the leading British authority on modern European history at the time and a key influence on A. J. P. Taylor during his Manchester years. Likewise, the historian Taylor's and the lawyer Taylor's understanding of how first Prussia, then the German nation had been systematically militarized in the age of Scharnhorst and Gneisenau, establishing mental continuities that lasted well into the Third Reich, were more than just remotely similar. ${ }^{59}$ And they were shared by another British historian who personally appeared on the Nuremberg and Hamburg scenes and whose understanding of German history bore unmistakable resemblance to that of Calvocoressi and the two Taylors.

John Wheeler-Bennett, at first sight, did not have much in common with A. J. P. Taylor. One a gentleman historian without a university degree but personally acquainted with half of Europe's conservative elites, ${ }^{60}$ the other a scholar notorious for his radical, often socialist inclinations, the two men shared a focus on "grand politics"; the rather traditional diplomatic history they wrote mostly fell into the great-men-of-history variety. They were also both closely acquainted with Namier, with whose deep distrust of German nationalism and antisemitism they essentially agreed. In Wheeler-Bennett's case, this had been a gradual process, starting with his early writings on the peace forced upon the Soviet Union at Brest-Litovsk (which Wheeler-Bennett interpreted as a key junction in the destabilization of Europe) and his Hindenburg biography, both published in Namier's Studies in Modern History series in the 1930s. Although he was impressed with the superior operational skills of the Prussian military, Wheeler-Bennett also portrayed German generals as ruthless and morally indifferent, obviously in the cases of Ludendorff and the ever-conspiring Schleicher, but also in the

\footnotetext{
${ }^{55}$ IMT, XXII, 295; Trials of War Criminals before the Nuernberg Military Tribunals, 15 vols. (Washington: Government Printing Office, 1949-1955 [henceforth TWC]), IX, 61.

${ }^{56}$ IMT, XXII, 521-23.

${ }^{57}$ See Valerie G. Hébert, Hitler's Generals on Trial: The Last War Crimes Tribunal at Nuremberg (Lawrence: University of Kansas Press, 2010).

${ }^{58}$ For biographical sketches see Jonathan A. Bush, "Soldiers Find Wars: A Life of Telford Taylor," Columbia Journal of Transnational Law 37 (1998-1999): 675-92, and Jonathan A. Bush, "Peter Calvocoressi. Obituary," The Independent, February 2, 2010.

${ }^{59}$ Taylor, The Course of German History, 35-39; TWC, X, 477-84. Cf. Linda Colley, Lewis Namier (London: Weidenfeld \& Nicolson, 1989), 99f.

${ }^{60}$ For his biography see Victoria Schofield, Witness to History: The Life of John Wheeler-Bennett (New Haven, CT: Yale University Press, 2012).
} 
more sympathetic portrait of Hans von Seeckt. In addition, Wheeler-Bennett's account of Weimar's final years of agony, rich with many inside observations gleaned from personal conversations in 1930s Berlin (where he had also met Passant), would prove highly influential for explaining why the first German democracy had failed. ${ }^{61}$

By the time Wheeler-Bennett arrived at Nuremberg, his stance on the German question had stiffened considerably. In a series of papers that he had penned for the Foreign Office's Political Intelligence Division during the war, the historian had strongly advised to come down hard on the military elite. "Unless the power and influence of the German General Staff is broken and destroyed," Wheeler-Bennett had noted in the spring of 1943, "the full measure of victory will not have been attained." The destruction of the Prussian army would have to be accompanied by that of the "old gods of power" so worshipped by the German people. ${ }^{62}$ The following year, on learning about the post-July 20 purges, Wheeler-Bennett merely commented that "If it is true that a number of the more distinguished generals, together with such civilians as Schacht, Neurath and Schulenburg have been eliminated, the Gestapo and the SS have done us an appreciable service in removing a selection of those who would undoubtedly have posed as 'good' Germans after the war, while preparing for a third World War."63

Entering Nuremberg only at the tail end of the first trial, Wheeler-Bennett's influence on the IMT should not be overestimated. Yet his expertise came in time for cross-examinations of those defendants to whom, as members of Weimar's conservative elite, he accorded particular blame for Hitler's assumption of power, that is, Papen, Neurath, and Schacht on whom he advised British deputy chief prosecutor David Maxwell-Fyfe in spring 1946. Whether his staying at the house of Francis Biddle meant he also influenced the American judge's views we do not know, ${ }^{64}$ but the eyewitness-turned-historian would leave his mark on the subsequent proceedings' preparations. His unflattering portraits of Otto Meissner, head of the president's office under Hindenburg and Hitler, and career diplomat Ernst von Weizsäcker were echoed by the prosecution in the Ministries case. Telford Taylor's presentation of the High Command case very much agreed with Wheeler-Bennet's newer writings-which, in turn, would soon reflect the historian's reliance on the evidence seen at Nuremberg. During the Manstein trial, both British prosecutors and judges would also turn to his firsthand recollections of the German military elite. ${ }^{65}$

Meanwhile, Edmond Vermeil's contribution came perfectly in time for the IMT. Not only did he publish a revised edition of his Essai in 1945, he also joined the French prosecution in person. Vermeil was very well placed for such an endeavor. Having enlisted with the Résistance after German occupation, he had eventually gone into exile to join De Gaulle's

${ }^{61} \mathrm{~J}$. W. Wheeler-Bennett, Hindenburg: The Wooden Titan (London: Macmillan, 1967 [1936]); J. W. Wheeler-Bennett, Brest-Litovsk: The Forgotten Peace, March 1918 (London: Macmillan, 1938); J. W. Wheeler-Bennett, The Nemesis of Power: The German Army in Politics 1918-1945 (London: Macmillan, 1954). Cf. J. W. Wheeler-Bennett, Knaves, Fools and Heroes: In Europe between the Wars (London: Macmillan, 1974), 15.

${ }^{62}$ On the Making of Peace, March 1943, St. Antony's College Library (StACL), Sir John Wheeler Bennett Papers, Series B, File 2.

${ }^{63}$ Top Secret, July 25, 1944, StACL, Wheeler Bennett Papers, Series B, File 2.

${ }^{64}$ David Maxwell-Fyfe to Hartley Shawcross, 20.6.1946, StACL, Wheeler Bennett Papers, Series C, File 1(d); John Wheeler-Bennett, Friends, Enemies and Sovereigns (London: Macmillan, 1976), 31-44; Schofield, Witness to History, 179-81.

${ }^{65}$ Wheeler-Bennett, Friends, Enemies and Sovereigns, 115. 
London organization. When the general's provisional government had to build up a prosecutorial organization from scratch in late summer 1945, the chief of counsel and until recently head of the Garde des Sceaux, François de Menthon, drew primarily on the Résistance networks. Like Neumann, Schorske, and Passant, Vermeil was thus recruited to the French delegation at Nuremberg. ${ }^{66}$

For those who were not yet familiar with his writings on Germany, he drew up a summary of the argument. On some thirty-five pages, Vermeil told the familiar story of German divergence to answer what he considered the fundamental question: "Comment admettre que l'Allemagne, fécondée au cours des siècles par l'Antiquité classique et le christianisme, par les idées de la liberté et de justice sociale, par l'héritage de l'Humanisme occidental, ait pu, sous prétexte de retrouver le secret de son héroïsme guerrier, secouer les plus hautes de sa culture et tenter de détruire la périphérie européenne." 67 In reply, Vermeil referred to the forces of Romanticism and pan-Germanism and told a story of lop-sided socioeconomic modernization, Bismarckian power politics, and imperial aspirations that had drawn a deep gap between the Reich's moral relativism and its western neighbors' deeply entrenched humanism: "Alors que les nations réunies autour de l'Atlantique conservent une certaine stabilité qu'elles doivent à la continuité de leur développement historique et à leurs traditions démocratiques, l'Allemagne du XIXe siècle nous apparaît comme un pays sans traditions intellectuelles, morales et politiques solidement établies." Vermeil explicitly expanded both historical responsibility and legal guilt to broader groups: "Hobereaux, grands industriels, diplomates et généraux sont aussi coupables que les Nazis qu'ils ont appelés au pouvoir, en finançant le régime et en l'orientant vers la guerre la plus atroce que le monde ait connue.... Les oligarchies complices vont comparaitre côte à côte devant leurs juges. Et ce n'est que justice.”68

In contrast to Neumann and Passant, Vermeil had no reason to complain that his advice went unheeded. On the contrary, the French prosecution presented the most historiographical of all cases-in-chief before the IMT, and Vermeil's influence showed in every line of Menthon's opening speech (which Vermeil had coauthored with his fellow historian, Pierre Renouvin, and Suzanne Bastid, a law professor from Lyon). ${ }^{69}$ Some prosecutorsamong them Edgar Faure, if we are to believe his retrospective comments-may have been sceptical of the express formulation of a Sonderweg narrative as a means of proving the profound reasons for German deviation and deformation and ultimately for Nazi

\footnotetext{
${ }^{66}$ Délégation française du TMI, undated, Archives d'Histoire Contemporaine (AHC), CD 4, Dossier 2; see Antonin Tisseron, La France et le procès de Nuremberg. Inventer le droit international (Paris: Prairies Ordinaires, 2014), 78-82, 135-41.

67 "How are we to accept that Germany, which, for centuries had been fertilized by classical Antiquity and Christianity, by the ideas of liberty and social justice, by the legacy of western humanism, should have been able, under the pretext of rediscovering the mysteries of its warrior heroism, to abandon the pinnacles of its culture and to attempt the destruction of the European periphery."

${ }^{68}$ The "lords of the manor, great industrialists, diplomats, and generals are just as guilty as the Nazis to whom they handed power, on account of their funding the regime and their directing it toward the most atrocious war the world has ever known ... The aiding and abetting oligarchs will appear before their judges side by side. And that is only just"; Edmond Vermeil, Les Crimes du Troisième Reich Schéma, undated [1945], AHC, CD 3, Dossier 1.

${ }^{69}$ Robert Falco, Juge à Nuremberg. Souvenirs inédits du procès des criminels nazis (Nancy: Arbre bleu, 2012), 73. Cf. Mathias Gemählich, Frankreich und der Nürnberger Prozess gegen die Hauptkriegsverbrecher $1945 / 46$ (Berlin: Lang, 2018), 188f.
} 
criminality. But Menthon, along with his aide Charles Dubost, stuck doggedly to Vermeil's script. In his opening speech, he paraphrased the scholar's summary and exhorted the fateful historical turn that Germany had taken in the nineteenth century. Germany, the French chief prosecutor explained, had undergone industrialization, "this metamorphosis of economic and social life, not only with an extraordinary brutality but at a time when she did not yet possess the political equilibrium and the cultural unity which the other countries of western Europe had achieved." Invoking the spectres of Fichte and Hegel, he condemned the two philosophers for paving the way to pan-Germanism and justifying war as a legitimate means of politics. Drawing a firm line between the corrupted ethics and politics of Germany, on the one hand, and the ideas of the French Revolution, battered but undefeated, on the other, Menthon and Dubost left no one in doubt that Nazi criminality epitomized an unprecedented and not to be tolerated breach of trust against western civilization: "Some of these crimes constitute attacks on the fundamental ... principles of liberty, equality, and fraternity which France proclaimed in 1789 and which the civilized states guarantee in perpetuity."70

Whatever Faure thought of Menthon's incrimination of Germany's erroneous philosophical and historical ways at the time, the defense attorneys were incensed. Evidently appreciating the broad assumptions that informed much of the French prosecution's case, several of the defense counsel attacked the theories expounded by Menthon and Dubost, vigorously denying that any excerpts from Fichte's Reden an die deutsche Nation could be taken as proof of "the first step to a leading astray of the German character." Instead, the French Revolution - that is, the very ideas of 1789 that Menthon and his team praised-had sparked the rise of nationalism and thus of war, and Napoleon's campaigns had further radicalized this trend. If any nation was to be held historically responsible for the excesses of nationalism, it was France. ${ }^{71}$

The French prosecution's historical drive was somewhat tempered when Menthon returned to his political career at Paris and was replaced by the more understated and physically frail former conservative cabinet minister, Auguste de Champetier de Ribes (who left much of the coordinating work to Dubost). Still, the French remained vocal proponents of continuing a trial program that reflected broader historical responsibilities. When Gustav Krupp's case was severed from the IMT because of his physical and mental inability to stand trial, it was the French delegation that eagerly backed the idea of follow-up proceedings in which Krupp — either Gustav or his son and heir Alfried - would be accompanied in the defendants' dock by a number of other prominent businessmen so as to show the complicity of German corporations in Nazi aggression. In the "trial that never was," 72 the Krupp concern would have been the frontrunner with its long history stretching back right to the Napoleonic wars and its phenomenal rise to the top of European industry in apparent harmony (and, so the argument went, causal relation) with the forging of a unified Reich under Prussian hegemony. Alfried Krupp would eventually stand trial at Nuremberg, and the prosecution narrative would indeed closely follow this storyline, relying first and foremost

\footnotetext{
${ }^{70}$ IMT, V, 375-77, 411; IMT, VI, 426f.; cf. Gemählich, Frankreich und der Nürnberger Prozess gegen die Hauptkriegsverbrecher 1945/46, 190-92.

${ }^{71}$ IMT, XVII, 499.

${ }^{72}$ Donald Bloxham, “"The Trial that Never Was': Why There Was No Second International Trial of Major War Criminals at Nuremberg," History 87, no. 285 (2002): 41-60.
} 
on Bernhard Menne's critical chronicles of Krupp's corporate history and, implicitly, on the broader interpretations of Kehr, Hallgarten, and others. ${ }^{73}$

Meanwhile the French decided to run a subsequent trial of their own. In a case that differed distinctly from the rest of the cases tried by the Tribunal général at Rastatt-mostly concentration camp atrocities and similar charges-Dubost's former Nuremberg colleague Charles Gerthoffer indicted Hermann Röchling and four of his managers for crimes against peace, war crimes, and crimes against humanity. Röchling had been shortlisted for the aborted second IMT and was understood to be Krupp's equivalent in the French zone of occupation: an iron and steel producing dynasty that went back well into the nineteenth century, whose rise had paralleled that of the Reich, and whose fortunes - notably in their Lorraine works but also in Röchling's support of the Sarre territory's return to Germany in 1935 - had been intricately tied up with the nation's political fate. The Röchlings, Dubost had alleged in 1946, "have always exercised a great industrial, financial, and political activity in the country.... Notoriously pan-Germanic, they made all efforts between the wars of 1870 and 1914-18 to Germanise the section of the Department of the Moselle where they had extended their undertakings.... The Roechlings appear to have embraced National Socialism along with the Ruhr industrialists and Krupp."74 That Hermann Röchling had already been tried and convicted of war crimes in the aftermath of World War I added another historical layer to the case. ${ }^{75}$ Again, not everyone may have been convinced of the historical reasoning in a criminal trial. But Telford Taylor, for one, appreciated that his French colleagues pursued a line very similar to his own. He advised his staff to back the Rastatt prosecutors (who in turn supplied documents and witness testimony to the Nuremberg staff), included parts of the case's record in the official edition of his own trial series, the Green Series, and awarded medals to his French comrades-in-arms. ${ }^{76}$

\section{Writing Nuremberg}

The fifteen volumes of the Green Series (because of the color of the binding), officially known as Trials of War Criminals before the Nuernberg Military Tribunals and published between 1949 and 1953, were not the only books that grew out of Nuremberg. It had been a key prerogative of the Allied prosecutors from the start to document the trials as intensely as possible and to establish a historical record on which contemporary and future generations of historians could draw. Robert Jackson had shown the way by publishing his pretrial "Report to the President" (a declaration of intent, really) in 1945, and he would continue along this line. A collection of correspondence and protocols of the London Conference, covering the talks on the IMT Charter and early preparations for the actual trial, was published in 1949. ${ }^{77}$ The volume supplemented the official record of the IMT, widely known as the Blue Series (again, for the color of the cloth they were bound in), which was collected in no less than forty-two heavy volumes, assembling the complete transcript as well as all

\footnotetext{
${ }^{73}$ See Priemel, The Betrayal, 173-79.

${ }^{74}$ French Prosecution to US Prosecution, August 31, 1946, NARA, RG 238, Entry 159, Box 1, Folder 5.

${ }^{75}$ See Tisseron, La France et le procès de Nuremberg, 287-90, and Priemel, The Betrayal, 213f., 218.

${ }^{76}$ Memorandum [Taylor] for the Secretary of the Army, January 4, 1949, NARA, RG 238, Entry 159, Box 1; TWC, XIV, 1061-143.

${ }^{77}$ Robert H. Jackson, ed., Report of Robert H. Jackson, United States Representative, to the International Conference on Military Trials, London, 1946 (Washington, DC: Government Printing Office, 1949).
} 
documents presented in evidence. As such, the edition could not be challenged as biased, but it fell short of Jackson's didactic impulse to drive home the lesson of German aggression and Nazi conspiracy as the key issues at stake before the IMT. Accordingly, he had his staff prepare yet another anthology, the Red Series, which included some of the available IMT materials but added a good number of prosecution briefs and reports that spelled out the central arguments of Jackson's mission: the conspiracy charge. ${ }^{78}$ None of these anthologies was edited by a historian; only the Green Series benefited from the input of John H. E. Fried, who had served as legal adviser to the subsequent tribunals and was to ensure the edition's impartiality from the judge's perspective. A lawyer by training, Fried's prewar monograph on Wehrmacht history and his study of Germany's forced labor system circulated widely in Nuremberg and gave him something of a historian's reputation-but this was as far as it went. $^{79}$

Plans for histories of the Nuremberg trials dated back to the earliest days of the proceedings. Appreciating that interpretative authority over what the trials actually meant would be a key to their legacy — notably with an eye to German critics - these plans were also motivated by the participants' wish to see their contribution adequately acknowledged. On the British side, Judge Birkett urged that "the B.W.C.E. should receive its due recognition," and the prosecutors were not disinclined. Spurred by Basil Liddell-Hart, then Britain's leading military historian, Shawcross and Maxwell-Fyfe contemplated the prospects of a monograph in early 1946. In addition to "something which is fairly short, snappy and sensational, adequately illustrated" for the general public, Shawcross suggested, "the more serious readers," and especially those at universities, would require a solid, 400- to 600-page analysis of the IMT. And who better to write such an account than a prosecution counsel?, he asked, and set out to discuss the idea with Lauterpacht and Passant. Meanwhile, as author of the volume planned for popular consumption, the names of Harold Nicolson-Vita Sackville-West's husband and a well-known figure in London's political and literary lifeand that of Robert Cooper, the Times correspondent covering the trial, were tendered ${ }^{80}$ Eventually, Cooper would accept the commission and publish his concise book with Penguin a mere year later; a German translation was printed simultaneously in Vienna and Krefeld. ${ }^{81}$ Whereas Cooper's was a factual, sober account that offered little in the way of broader historical interpretation, his colleague Victor Bernstein, who reported from Nuremberg for PM Magazine, produced a very different tome. Hitting the book stacks the same year, Bernstein's narrative reflected the analytical approach of those parts of the US prosecution who had stressed the deep roots of German functional elites' cooperation, including the military, industry, and science. ${ }^{82}$

\footnotetext{
${ }^{78}$ IMT, 42 vols.; Nazi Conspiracy and Aggression: Office of United States Chief of Counsel for Prosecution of Axis Criminality, 8 vols. + 2 suppl. (Washington, DC: Government Printing Office, 1946-1948).

${ }^{79}$ See the TWC prefaces.

${ }^{80}$ Shawcross to DMF, February 8, 1946, The National Archives (TNA), WO 311/709; Liddell Hart to Shawcross, November 21, 1945, TNA, WO 311/709; Dupree to Sinclair, April 24, 1946, TNA, TS 26/ 172; Birkett to Sinclair, April 8, 1946, TNA, TS 26/173.

${ }^{81}$ R. W. Cooper, The Nuremberg Trials (London: Penguin, 1947); Robert W. Cooper, Der Nürnberger Prozess (Krefeld: Scherpe, 1947); Robert W. Cooper, Das letzte Kapitel (Wien: Humboldt, 1947).

${ }^{82}$ Victor H. Bernstein, Final Judgment. The Story of Nuremberg (New York: Boni \& Gaer, 1947). Alan Bullock, who reviewed both books for International Affairs (1948) tellingly preferred Cooper's narrative over Bernstein's.
} 
The search for either a lawyer or a professional historian to write the academic account of the IMT proved more difficult. When the initial idea to approach G. M. Trevelyan came to nothing, John Wheeler-Bennett seemed the obvious choice. Already affiliated to the British Foreign Office, he agreed to take care of the historical chapters while leaving the more strictly legal matters, as well as a recap of post-World War I reparations policy-which together with the war-guilt issue had provoked the "furor teutonicus," as a draft chapter noted-to diplomat Patrick Dean and Colonel Henry Phillimore, both members of the BWCE. With all three authors tied up in other obligations, however, the Nuremberg manuscript made painfully slow progress. Dean had been promoted to head of the Foreign Office's German Political Department; Phillimore was supposed to write the history of the War Office's POW branch; and Wheeler-Bennett had accepted co-editorship of the massive Documents of German Foreign Policy project, a function in which he cooperated with Passant and Langer and which covered much of the same ground as the Nuremberg documents. ${ }^{83}$ In late 1948, Wheeler-Bennett confessed to Shawcross that the book was still far from completion, and after another fourteen months, the picture had not changed significantly. ${ }^{84}$ By the early 1950s, it became obvious that no academic treatise was forthcoming and WheelerBennett finally abandoned the project. Instead, his Semblance of Peace would include a chapter on Nuremberg that fell far behind initial expectations in terms of depth and precision but at least met Birkett's hope for praise of the British contribution to the IMT: their team, Wheeler-Bennett stated, had been a "a forcing-ground for genius." 85 Meanwhile and independent from these official, stage-managed projects, Peter Calvocoressi penned his own account of the IMT. His plainly titled Nuremberg combined sober legal analysis with passionate historical narrative, which backed up the story of how "the root of all the troubles which Germany brought on Europe was to be found in something which was usually called German militarism." 86 The concise volume would herald Calvocoressi's illustrious career as author and publisher in both history and international affairs over the following decades.

Abroad, the American publication plans did not live up to the prosecutors' expectations either. In contrast to the Blue Series's exhaustive coverage of the IMT, the much shorter Green Series did not include the complete record of the subsequent proceedings but only excerpts as the War Department cut funding, reflecting the changing tide of German reintegration and the priorities of anti-Soviet propaganda. As a result, a comprehensive and authoritative monograph on both IMT and NMT (which had been in the pipeline since the late 1940s) never materialized. An Ivy League-based study group, which included such eminent scholars as Neumann, Carl J. Friedrich, and Gordon Craig, along with Nuremberg prosecutors Telford Taylor and Benjamin Kaplan, made repeated efforts to secure funding for Fried, who had been groomed for the authorship of said book (and

\footnotetext{
${ }^{83}$ Incidentally, Rohan Butler became senior editor of the Documents on British Foreign Policy in 1955; Wheeler-Bennett, Friends, Enemies and Sovereigns, 68, 71; Sacha Zala, Geschichte unter der Schere politischer Zensur. Amtliche Aktensammlungen im internationalen Vergleich (Munich: Oldenbourg, 2001), 205, $227,242$.

${ }^{84}$ Wheeler-Bennett to P. Dean, October 24, 1946, StACL, Wheeler Bennett Papers, Series A, Envelope 5 (War Trials); Wheeler-Bennett to Shawcross, October 19, 1948 and Dean to Wheeler-Bennett, January 14, 1950, StACL, Wheeler Bennett Papers, Series C, File 1(d); cf. Schofield, Witness to History, 181.

${ }^{85} \mathrm{John}$ Wheeler-Bennett and Anthony Nicholls, The Semblance of Peace: The Political Settlement after the Second World War (London: Macmillan, 1972), 391-416, esp. 408. Cf. Wheeler-Bennett, Friends, Enemies and Sovereigns, $42 \mathrm{f}$.

${ }^{86}$ Peter Calvocoressi, Nuremberg: The Facts, the Law and the Consequences (London: Chatto \& Windus, 1947), 93.
} 
who was in contact with Wheeler-Bennett), but ultimately failed. ${ }^{87}$ Eventually, Taylor would take on the project himself, yet with a delay of four decades and the manifest limitation that his Anatomy of the Nuremberg Trials—half memoir, half monograph-covered only the IMT. 88

Yet Telford Taylor put his Nuremberg experience to immediate historiographical use, and so did Wheeler-Bennett. Both went on to publish detailed studies that exploited the evidence assembled at Nuremberg to the fullest and continued the narratives spun by the prosecution. In a remarkable coincidence, Taylor and Wheeler-Bennett chose identical subject matters (and arrived at fairly identical conclusions, too), though in reverse order: whereas the former chief prosecutor started with a study of what he considered the fateful alliance of Sword and Swastika, that is, militarism and Nazism, and more Wehrmacht-related studies before writing his opus magnum, a weighty analysis of the 1938 Munich Conference, ${ }^{89}$ Wheeler-Bennett instantly turned to Munich. Rapidly working through the documentary evidence established in the IMT as well as in the subsequent cases, Wheeler-Bennett largely confirmed the picture drawn by the prosecution. As usual focusing on individual protagonists, the historian told the story of rekindled "ambitions of the Pan-German League" and the Nazi plan for aggression, which had been carried out through a combination of "the capacity of the Germans for sheep-like conformity to leadership," "all the guile of the old pre-war duplicity of Prussian diplomacy," and a ruthless military that "regarded war as an instrument of policy" rather than an evil that was to be avoided at all cost. ${ }^{90}$

Written while the trials continued and published in 1948, Munich was immediately followed by The Nemesis of Power (1953) on which Wheeler-Bennett began working in the last year of the Nuremberg tribunals. In his book, which again drew on the evidence from the war crimes proceedings (and advice from E. J. Passant and Lewis Namier whose own 1948 Diplomatic Prelude strongly built on the Nuremberg defendants' testimony), ${ }^{91}$ he returned to his long-time favorite subject, the German military. Opening with a telling epigraph from Tacitus, claiming that the German tribes had no taste for peace, he still recognized the brilliance of Germany's military leaders — notably Seeckt — but the story now had a distinctly more sinister tone than in his Hindenburg biography. Like Taylor, Wheeler-Bennett spoke of a "military caste" that had dominated Prussia and Germany through the institution of the general staff for "very little short of a century and a half," joining hands with the "Junkers, the die-hard Conservatives, the industrial Barons," and the pan-German League activists, those "most ardent of reactionary jingoes." 92 This read like the NMT trial design turned into historical narrative, and indeed it was. Wheeler-Bennett's conclusions were therefore bleak. The militarist spirit of Germany had to be rooted out once and for all, he maintained, and although he was enough of a realist to accept the FRG's significance in

\footnotetext{
${ }^{87}$ See their correspondence in 1949-1950: University at Albany, Special Collections \& Archives, John Fried Papers, Box 2, Folder 87.

${ }^{88}$ Telford Taylor, The Anatomy of the Nuremberg Trials: A Personal Memoir (New York: Little Brown, 1992), 50.

${ }^{89}$ Telford Taylor, Sword and Swastika: Generals and Nazis in the Third Reich (New York: Simon \& Schuster, 1952); Telford Taylor, Munich: The Price of Peace (New York: Vintage, 1979).

${ }^{90}$ Wheeler-Bennett, Munich, 11, 207, 226.

${ }^{91}$ Lewis B. Namier, Diplomatic Prelude 1938-1939 (London: Macmillan, 1948); cf. Colley, Lewis Namier, 28; Ernest James Passant, A Short History of Germany 1815-1945 (Cambridge: Cambridge University Press, 1959), 242-44, in turn, relied strongly on Wheeler-Bennett's Hindenburg and The Nemesis of Power.

${ }^{92}$ Wheeler-Bennett, The Nemesis of Power, 4-6, 62f., $273 \mathrm{f}$.
} 
the Cold War, Wheeler-Bennett saw fit to warn explicitly against placing too much trust in German soldiers. If integration and remilitarization were inevitable, constant vigilance was of the essence- a point on which, again, the historian very much agreed with the prosecutor. ${ }^{93}$

Taylor and Wheeler-Bennett, of course, were not alone in eagerly screening the Nuremberg record for research purposes. Among the first historians to consult the NMT materials was George Hallgarten, who had briefly served as war-crimes consultant to the Department of War and who now happily plunged into the wealth of material made available in the aftermath of occupation. Unsurprisingly, he found his earlier interpretations of German history wholly supported by the Nuremberg evidence. Writing to Alfred Vagts, the German historian who like most of his fellow émigrés would not return to Germany, excitedly reported that the documents "exceed everything a poor devil such as I could ever offer." In fact, he noted, they might even furnish him "the material for a continuation of Pre-War-Imp[erialism] down to 1945." In the end, however, Hallgarten never advanced beyond a mere sketch, published in 1955, which took the story only to 1933 and fell far short of the empirical richness of his earlier work. ${ }^{94}$

Not everyone shared Wheeler-Bennett's and Hallgarten's enthusiasm for the Nuremberg materials, though. And it was A. J. P. Taylor, of all people, who came out with some of the harshest criticism of what he considered undue reliance on the tribunals' sources. In his controversial Origins of the Second World War, Taylor censured the use of the evidence as a failure to apply rigid standards of critical research. In a passage worth quoting at some length, the Oxford don, always looking for a good fight, came close to brushing Nuremberg's record nearly completely aside:

The evidence of which there is too much is that collected for the trials of war criminals in Nuremberg. Though these documents look imposing in their endless volumes, they are dangerous materials for a historian to use. They were collected, hastily and almost at random, as a basis for lawyers' briefs. This is not how historians would proceed. The lawyer aims to make a case; the historian wishes to understand a situation. The evidence which convinces lawyers often fails to satisfy us; our methods seem singularly imprecise to them. But even lawyers must now have qualms about the evidence at Nuremberg. The documents were chosen not only to demonstrate the war guilt of the men on trial, but to conceal that of the prosecuting Powers. If any of the four Powers who set up the Nuremberg tribunal had been running the affair alone, it would have thrown the mud more widely.... Given the Four Power tribunal, the only possible course was to assume the sole guilt of Germany in advance. The verdict preceded the tribunal; and the documents were brought in to sustain a conclusion which had already been settled. ${ }^{95}$

What seemed a point of methodology was in fact one of interpretation. A. J. P. Taylor was incensed by what he considered the perpetuation of a flawed historical reading that had been judicially approved at Nuremberg, that is, the conspiracy theory according to which Hitler and a not-too-numerous circle of plotters had planned and executed war, atrocities, and

\footnotetext{
${ }^{93}$ Wheeler-Bennett, The Nemesis of Power, viii-x; Telford Taylor, "Arms and the Germans," Harper's Magazine 1950, no. 3, 23-29.

94 “Pre-war Imperialism" referred to his PhD dissertation; Hallgarten to Vagts, March 10,1947, December 14, 1947, January 14, 1948, and March 31, 1948, BA, N 1269/7; George W. F. Hallgarten, Hitler, Reichswehr und Industrie. Zur Geschichte der Jahre 1918-1933 (Frankfurt: EVA, 1955).

${ }^{95}$ A. J. P. Taylor, The Origins of the Second World War (London: Folio Society, 1998 [1961]), 25. Norman J. W. Goda, “A. J. P. Taylor, Adolf Hitler, and the Origins of the Second World War," International History Review 23 (2001): 97-124, points to the consistencies in Taylor's interpretation while coming down hard on the deficits in his historical craftsmanship.
} 
mass murder. Taylor's own interpretation of the allegedly rather "ordinary" statesman Hitler, often mistaken as a relativization of Hitler's responsibility and Nazi crimes, was in fact intended to counter the apologetic conclusions drawn from Nuremberg that he found had come close to acquitting the German people in its entirety. Instead, he posited in an argument that was essentially consistent with The Course of German History, that aggression, antisemitism, and racial hegemony had been the German people's national project, which Hitler had implemented rather than invented, helped by hapless international politicians in the 1930s. In short, Taylor was railing against what he called the "Nuremberg thesis" of a mad, racist Hitler and his henchmen, which his colleagues Alan Bullock and Hugh Trevor-Roper championed (or so Taylor said) and "simple-minded Germans" were only too willing to adopt. ${ }^{96}$

His argument was awkward, not so much due to his usual penchant for exaggeration or the vitriol of his formulations but because he misread the Nuremberg record. Focusing only on the IMT and here exclusively on the case as pleaded by Jackson, Taylor missed the very complexity of the trial series he had helped to shape. Neither the Vermeil-inspired French case before the four-power tribunal nor the Sonderweg interpretations as formulated by the prosecutors in the NMT (which were, if anything, wholly in accord with Taylor's own reading) figured in the historian's attack on the "Nuremberg thesis." This was sloppy work, and accordingly not only Bullock and Trevor-Roper-both of whom strongly relied on the IMT records for their Hitler-centric accounts-hit back. ${ }^{97}$ Although in politer terms than his colleague, Wheeler-Bennett admonished A. J. P. Taylor that rather than simply discarding the Nuremberg record as unusable historians ought to apply "those acid tests of scholarship which are essential in the use and evaluation of all such material." 98

Yet none of the British historians appreciated that they shared a two-sided angle, which significantly narrowed their respective vision of the Third Reich and its portrayal at Nuremberg: on the one hand, a focus on individual "statesmen" (to which criminal trial records lent themselves easily if read to that end), on the other, a near-exclusive interest in the advent of Nazi rule and the regime's war preparations (which echoed the IMT's conspiracy count). ${ }^{99}$ Had they cared to write about the actual war, about occupation in all its facets, and notably about the policies of extermination, other parts of the Nuremberg corpus would have helped in drawing a more complex picture. Yet it was the origins of the war they were ostensibly after, not those of the Holocaust, and it would be left to the intentionalistfunctionalist debate of the following decades to reexamine the Nuremberg evidence and find that it offered material for both readings. ${ }^{100}$

\footnotetext{
${ }^{96}$ Taylor, The Origins of the Second World War, 2. Cf. Cole, A. J. P. Taylor, 170-95.

${ }^{97}$ The debate has extensively covered, among others in Burk, Troublemaker, and Gordon Martel, ed., The Origins of the Second World War Reconsidered: A.J. P. Taylor and the Historians (London: Routledge, 1999).

${ }^{98}$ Wheeler-Bennett, The Semblance of Peace, 414. Cf. Wheeler-Bennett, Friends, Enemies and Sovereigns, $65 f$.

${ }^{99}$ See the classical study by Alan Bullock, Hitler: A Study in Tyranny (London: Odhams, 1952) and his 1968 Raleigh Lecture, "Hitler and the Origins of the Second World War," Proceedings of the British Academy 53 (1968): 259-87, both strongly relying on the Nuremberg record.

${ }^{100}$ For two different readings see Bloxham, Genocide on Trial, 202-06, 218-20, and Kim Christian Priemel, "Beyond the Saturation Point of Horror: The Holocaust at Nuremberg Revisited," Journal of Modern European History 14 (2016): 522-47; on historians' "hantise des origines," see Bloch, Apologie pour l'histoire ou métier d'historien, $53 \mathrm{f}$.
} 


\section{Conclusion: Nuremberg's Rebound Effects}

The debate among the four Oxford historians pointed to some of the principal methodological problems postwar historians encountered in conducting research on the Third Reich and its crimes. For several decades, the Nuremberg record would be the single most important corpus of sources, and to this day historical research on the Nazi era continues to draw on the massive amounts of material collected and registered by the Allies. ${ }^{101}$ The "acid tests of scholarship" by now are a standard procedure of historiographical work, if sometimes more strongly observed in rhetoric than in practice.

If A. J. P. Taylor's criticism had a point that his antagonists missed, he still failed to understand that it was not so much about facts - whether or not some evidence was produced in court whereas other proof was not — but about the underlying interpretations that organized these facts and thus constituted the trials' deep structure. Indeed, Nuremberg amply illustrated the persistence of historical narratives in and through transitional trials. Historical explanations of how the rise of National Socialism and the appalling, initially incredible crimes of the Third Reich could be accounted for abounded especially in the prosecution ranks. The discourse on German political and economic, philosophical and social divergence had been building up for decades and had resulted in a strong consensus on German divergence from the "right," that is, western evolution. How pervasive this narrative was became apparent in the review of a short book on War Crimes from the pen of exiled Polish lawyer Manfred Lachs on the eve of the IMT. By all accounts a factual, strictly legally minded treatise, the Manchester Guardian's reviewer still saw it as proof that the upcoming proceedings would be "the trial of Nazi heresy by western orthodoxy."102 Thus the Sonderweg paradigm - at which various historians in Germany proper as well as in France, Britain, and the United States arrived-came to inform much of the Nuremberg trials and indeed served as a counterfoil to conspiracy (and frequently also psychopathological) interpretations that focused on Hitler's "criminal clique." Many of the historians who adhered to such interpretations contributed, directly or indirectly, to the war crimes proceedings where prosecutors were grateful for overarching narratives that promised to render plausible why German elites had genuinely differed from their opposite numbers abroad.

However, very few, if indeed any of these historians reflected on their own role in crafting Nuremberg's narratives. Scholars such as Hallgarten and Wheeler-Bennett were quite happy to find in the trials' transcripts and documents evidence that vindicated their theories. Apparently, they never considered that they might have had a part in the specific composition of the Nuremberg record, thus overlooking the hermeneutic circularity of their work. Others broadened the scope while continuing along the same lines of interpretation. Hajo Holborn's famous article on German Idealism in the Historische Zeitschrift, then still the most important historiographical journal in the German language, would once more delineate the special path that Germany had followed over the past two centuries: influenced by romanticist ideas, ingrained authoritarianism, persistent feudalism, and misunderstood

\footnotetext{
${ }^{101}$ Gerhard Weinberg, “The Setting and Significance of the Nuremberg Trials: A Historian's Perspective," in Nazi Crimes and the Law, ed. Nathan Stoltzfus and Henry Friedlander (Cambridge: Cambridge University Press, 2008), 35-41.

${ }^{102}$ A. W. J., "War Criminals," Manchester Guardian, September 5, 1945: 3; cf. Manfred Lachs, War Crimes: An Attempt to Define the Issue (London: Stevens \& Sons, 1945).
} 
Hegelianism. ${ }^{103}$ So would his former R\&A colleague, Leonard Krieger, whose The German Idea of Freedom traced back German divergence to a cultural failure to understand the essence of western liberal thought. ${ }^{104}$ Hans Rosenberg's influential studies in social history, meanwhile, could be read as a prequel to Kehr's earlier work. ${ }^{105}$

Rebounding from the Nuremberg arena, the Sonderweg paradigm would become the most influential interpretation in postwar German history: bitterly contested by some, usually older German historians who embraced the conspiracy interpretation and insisted that National Socialism had been an aberration from, not the logical result of, German history (though also by dogmatic Marxists who held that the Nazi variant of fascism had merely been the most imperialist form of capitalism); emphatically embraced by others, mostly younger scholars who were keenly searching for new master narratives. Whether "Kehrites" or not, ${ }^{106}$ the work of historians such as Hans-Ulrich Wehler and Heinrich August Winkler — aspiring to grand, if not outright monumental, histories — was indebted to their antecedents: Wehler to Rosenberg and Kehr, Winkler to Krieger. And although professional historiography has been said to have abandoned the "special path" for good, reports of its death may be exaggerated. Winkler's Long Road West has gone through multiple editions since 2000, including an English translation in 2007. The Nuremberg trials, incidentally, figure but marginally in the 1,200 pages of Winkler's work, suggesting a surprising unawareness of intellectual parentage. ${ }^{107}$

Nuremberg's catalytic role in articulating and disseminating the Sonderweg paradigm may seem idiosyncratic. Indeed, the amount of academic scrutiny and elaboration that went into analyzing German history in general and the Nazi era in particular before, during, and after the Nuremberg trials was without precedent then and has not been repeated since. The number of historians involved in the Nuremberg project alone is highly unusual. And yet the general pattern would seem to apply to many other trials of Nazi-era crimes, too, which either could or would not avoid, namely, the Eichmann or the Frankfurt Auschwitz trials, to accomplish historiographical analysis in the courtroom. ${ }^{108}$ Such efforts-at Nuremberg no less than at Jerusalem, Frankfurt, or the more recent Demjanjuk case in Munich-have often met with harsh criticism from various sides: by those such as Hannah Arendt, who wished the law would not dabble in what it ought

\footnotetext{
${ }^{103}$ Hajo Holborn, "Der deutsche Idealismus in sozialgeschichtlicher Beleuchtung," Historische Zeitschrift 174 (1952): 359-84. See also Ludwig Dehio, "Deutschland und die Epoche der Weltkriege," Historische Zeitschrift 173 (1952): 77-94.

${ }^{104}$ Leonard Krieger, The German Idea of Freedom (Boston: Beacon Press, 1957).

${ }^{105}$ Hans Rosenberg, Bureaucracy, Aristocracy, and Autocracy: The Prussian Experience 1660-1815 (Cambridge, MA: Harvard University Press, 1958).

${ }^{106}$ See Hans-Jürgen Puhle, "Zur Legende von der 'Kehrschen Schule,", Geschichte und Gesellschaft 4 (1978): 108-19; cf. Helmut Walser Smith, "When the Sonderweg Debate Left Us," German Studies Review 31 (2008): 225-40.

${ }^{107}$ Heinrich August Winkler, Der lange Weg nach Westen, 7th ed., 2 vols. (Munich: Beck, 2010). Krieger's influence is also discernible in Liah Greenfeld's work; see her recent Nationalism: A Short History (Washington, DC: Brookings Institution Press, 2019).

${ }^{108}$ Lawrence Douglas, The Memory of Judgment: Making Law and History in the Trials of the Holocaust (New Haven: Yale University Press, 2001), 97-182; David Cesarani, Becoming Eichmann: Rethinking the Life, Crimes, and Trial of a "Desk Murderer" (Cambridge: DaCapo Press, 2006), 245-352; Rebecca Wittmann, Beyond Justice: The Auschwitz Trial (Cambridge, MA: Harvard University Press, 2005); Devin Pendas, The Frankfurt Auschwitz Trial, 1963-1965: Genocide, History, and the Limits of the Law (Cambridge: Cambridge University Press, 2006).
} 
not do; by historians who felt either the law or its agents were ill equipped to deal with the nuances of context and contingency; and by lawyers themselves who would have preferred not to be burdened with the extra responsibility of writing history in the courtroom. ${ }^{109}$

Such wishes express a longing, perhaps understandably, for an imagined epistemological state of grace in which law and history, jurisprudence and historiography remain each safely within their own confines. The Nuremberg experience, however, not only illustrates the futility of such yearnings; it also tells a cautionary tale of the dangers historians run into when they use judicial records selectively, with too small a grain of salt, or without a sound understanding of the transformations to which judicial procedure subjects historical arguments. It was precisely for these reasons - the antagonistic trial setting, criminal law's personalizing logic, and the strictures of legal subsumption - that a generation of influential historians failed to appreciate both the historiographical complexity built into the trials and the circular dynamics of their own reasoning.

UNIVERSITY OF OSLO

${ }^{109}$ Arendt, Eichmann in Jerusalem, 253; cf. Wittmann, Beyond Justice, 271f.; Pendas, The Auschwitz Trial, 22; Angelika Benz, Der Henkersknecht. Der Prozess gegen John (Iwan) Demjanjuk (Berlin: Metropol, 2011), 127f., 234; Lawrence Douglas, The Right Wrong Man. John Demjanjuk and the Last Great Nazi War-Crimes Trial (Princeton: Princeton University Press, 2016). 